\title{
LAPIDAR PERCEPTION OF TERRORIST THREATS IN THE INSTITUTIONS OF EDUCATION
}

\author{
Sylwester PNIAK \\ MILITARY UNIVERSITY OF TECHNOLOGY
}

\begin{abstract}
The author attempts to bring closer the perception of terrorist threats in educational institutions. For the sake of objectivity of the analysis, he compiles the research carried out by the Public Opinion Research Center presenting the sense of security in the country and the perception of terrorist threats, and his own research carried out in some educational institutions. Analyzing the results and paying attention to the guidelines of the Ministry of National Education, he defines the construction of an initial plan of training activities as a part of the "Safe School" project.

Keywords: security of educational institutions, terrorist threats, students' safety, preparation of schools for terrorist threats.
\end{abstract}

\section{Introduction}

Modern times determine an escalation of threats that every social group must face. Terrorism belongs to the group of asymmetric threats which are of particular importance.

Organized crime and terrorism are particularly negative phenomena of today. The forms as well as the manifestations of the threats that they bring with them create some serious consequences for the citizens. The evolution of organized crime and terrorism has entered the sphere of the Internet, and therefore cybercrime and cyberterrozym. These are the areas in which the maintenance of an appropriate level of security plays a priority role. This is due to the connection between a number of systems with the global network, the correlation of which is necessary to ensure the interaction of social groups, their security, control of activities etc.

However, the non-direct forms of criminal activity, and above all that one taking the most brutal form - terrorism, do not lose their importance but, on the contrary, take a global turn. The daily reports of the national information groups in the national and, in particular, in the world dimension, illustrate the seriousness of events and their consequences. Observing the contemporary global situation, it must be stated that the probability of occurrence of a terrorist incident is increasing. Although the threat of terrorist attacks in Poland is relatively low, their dynamism can change this level at any time. 
One of the places particularly exposed to terrorist attacks, next to the governmental facilities, public facilities, such as theaters, cinemas, hotels, restaurants, etc., are the institutions of education.

In 2017, the Ministry of National Education recognised the need to shape an appropriate attitude among the members of permanent and non-permanent education institutions. A set of instructions concerning the appropriate behavior in the event of a terrorist attack have been directed to headteachers. Pedagogues are trained in their behavior in the event of an intrusion of a person with a weapon, socalled active shooter, or an explosive load. The knowledge acquired by the teachers is successively transferred in an accessible form to their students.

The above actions induce some considerations about the effectiveness of the training undertaken and the way of transferring knowledge. In addition, undertaking a nationwide training initiative in educational institutions illustrates the seriousness of the situation which we are to face. Developing from the earliest years some appropriate responses on the possibility of a terrorist attack, a situation of a hostage, or an active shooter, not only gives a direct insight into the manner of actions of the attackers, but it also allows to work out a pattern of behavior when a given crisis situation occurs.

\section{A sense of security among the public}

Shaping security in educational institutions results from a general feeling of threat among the citizens. However, for an objective analysis of the society's attitude towards terrorist threats, the identification of general security in the country with regard to the perception of terrorist threats should be taken into account.

The Center for Public Opinion Research (CPOR) conducts annual public opinion surveys covering the sense of security of Poles. On the basis of this, one can observe the changes and tendencies in the perception of security, and often it can be deduced what they were caused by. The dynamically changing political, economic and business situation of the country also creates the relation between the security and threats.

According to a research carried out by CPOR, recent years have been characterized by high levels of a sense of security of $86 \%$. In 2018, there is a slight decrease in relation to the previous year, amounting to three percentage points (Figure 1). However, despite the slight decrease, most Poles believe that they feel safe in the country.

A research conducted in 2018 by CPOR using the method of direct computer aided interviews (CAPI) on a random sample of adult inhabitants of Poland, numbering 1140 people, shows that there are relatively few negative opinions about the sense of security in Poland (11\%). The best situation in Poland is assessed by pupils and students, administrative and office employees, as well as self-employed workers. 


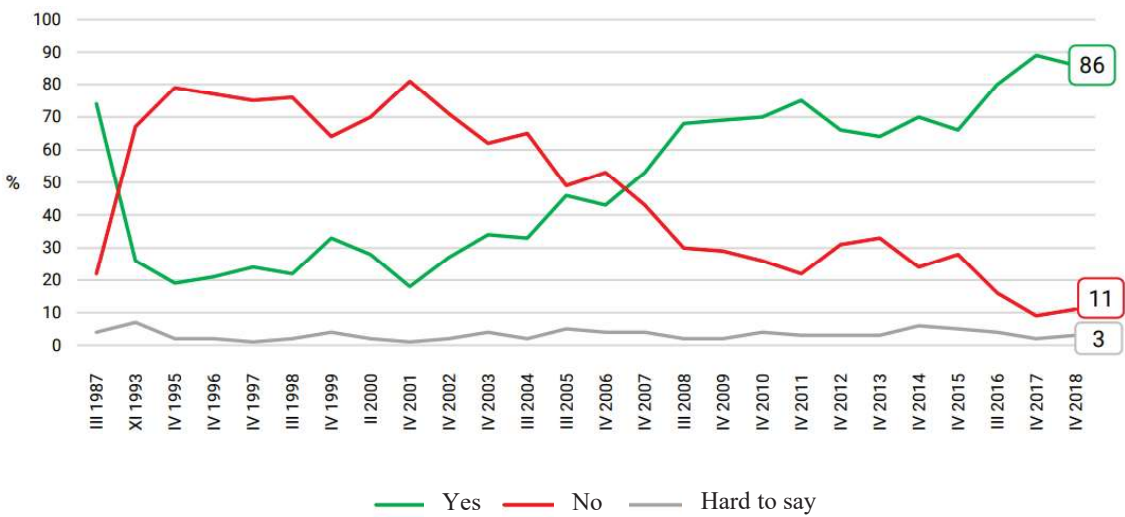

Fig. 1. Do you think Poland is a country where you live safely?

Source: Poczucie bezpieczeństwa i zagrożenia przestępczością. Komunikat z badań, nr 61/2018, Centrum Badania Opinii Społecznej, Warsaw, May 2018, p. 1, [online],

[in:] https://www.cbos.pl/SPISKOM.POL/2018/K_061_18.PDF [access 11.01.2019]

Comparing the results of research from particular years and paying attention to the changes in the sense of security, it can be observed that in the period from 1993 to 2007 , Poland was perceived by its citizens as a country where people did not live safely. The highlight in the period mentioned was the year 2001, where the sense of danger was over $80 \%$. It is worth noting that the research from 2001 was carried out in April, thus the terrorist World Trade Center attack of September 11, 2001, had no impact on such a negative perception of the security in Poland. The authors of the presented analysis, justifying the reason for such a low sense of security in the given period, indicate that public opinion mostly received news from the mass media. In turn, individual respondents' observations, experiences and conclusions covering security matters are overshadowed by external commentators ${ }^{1}$. In addition, the '90s of the last century shaped the stereotype of Poland as a dangerous country, with a widespread criminality and its significant level of brutalization. Thanks to such a solution, the media fought with violence in pursuit of sensational information that guaranteed greater viewership ${ }^{2}$.

In the following years, the upward trend of the sense of security is strongly visible, displacing the negative attitude among the citizens. However, political and economic changes, global security incidents affect the visible anomalies to a greater or lesser extent.

Political changes, migration problems, the activities of radical groups exerting pressure on individual states have not contributed to changing the public attitude

1 Cf. Poczucie bezpieczeństwa na co dzień. Komunikat z badań, BS/53/2008. CBOS, Warsaw, March 2008, p. 3, [online], [in:] https://www.cbos.pl/SPISKOM.POL/2008/K_053_08.PDF [access 12.01.2019].

2 G.B. Szczygieł, K. Lasowska, W. Filipowski, E.M. Guzik-Makaruk, E. Zatyka, Poczucie bezpieczeństwa obywateli i jego zagrożenia (założenia badawcze), [w:] L. Paprzycki, Z. Rau (red.), Praktyczne elementy zwalczania przestepczości zorganizowanej i terroryzmu. Nowoczesne technologie i praca operacyjna, Wolters Kluwer Polska, Warsaw 2009, p. 344-345. 
in perceiving the sense of security in the country. Nevertheless, a three-percent reduction in the security in recent years may indicate the beginning of a downward trend. Taking into account the current global situation, and in particular the non-transparent European situation, the described sequence seems to be very real.

Considering the above, it can be concluded that the sense of security is diversified and interpreted by the society depending on the accepted valuation of information, which is presented by the media and external broadcasters. Individual experiences of a person who is a witness of the breach of security have a greater impact on the formation of awareness and sense of security, the interpretation of threats and, above all, the final result.

\section{Perception of terrorist threats by the society}

The surveys carried out in 2016 by CPOR using the direct computer-assisted interview method, on a random sample of 1033 persons, include the results of the research presenting terrorist threats in Poland ${ }^{3}$. Comparing the opinions of the respondents with the sense of security of the citizens, and the emergence of a general threat of terrorism in Poland, one can notice some differences in the presented results. Taking into account the time interval of both studies, in the first case the result is classified at the level of 65-70 percent, while in the other the average is 50 percent (Figure 2). In connection with the above, there is a concern among the citizens about the occurrence of a terrorist event.

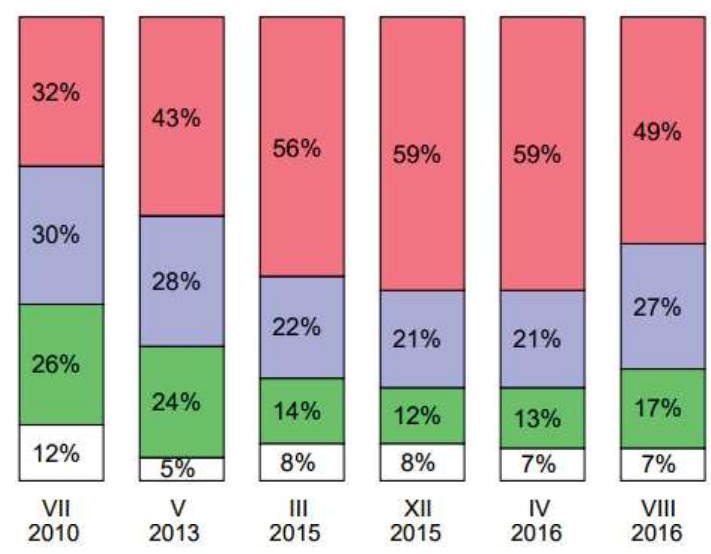
$\square$ There is a real threat of terrorism in Poland
$\square$ The threat of terrorism in Poland is exaggerated
$\square$ There is no real threat of terrorism in Poland
$\square$ Hard to say

Fig. 2. What is the closest to your views on the threat of terrorism in Poland? Source: Zagrożenie terroryzmem. Komunikat z badań, nr 127/2016,

Centrum Badania Opinii Społecznej, Warsaw, September 2016, p. 1, [online], [in:] https://www.cbos.pl/SPISKOM.POL/2016/K_127_16.PDF [access 13.01.2019]

\footnotetext{
Zagrożenie terroryzmem. Komunikat z badań, nr 127/2016, CBOS, Warsaw, September 2016, [online] [in:] https://www.cbos.pl/SPISKOM.POL/2016/K_127_16.PDF [access 13.01.2019].
} 
One of the factors influencing the research was undoubtedly the terrorist attacks in the world and the European Union countries, which are important in the perception of terrorist threats by the society. Taking into account events of a terrorist character, i.e.:

- July 2011 - extremist Anders Breivik carried out a bomb attack in Islo and a massacre on the island of Utoya, which killed 77 people altogether;

- March 2012 - Islamist Mohamed Merah murdered three soldiers in Montauban and shot three children in front of the Jewish school in Toulouse, one adult and one person severely injured;

- May 2013 - two men brutally murdered a British soldier in East London;

- May 2014 - in the shooting that took place in the Jewish Muzemum in Brussels, three people were killed and one was injured;

- January 2015 - the assassination of The offices of Charlie Hebdo, in the shooting twelve people were killed;

- On the following days, the assassins murdered one policewoman and four random persons;

- November 2015 - a series of coordinated attacks, including the Batalcan concert hall. In total, 130 people were killed, about 350 were injured;

- March 2016 - a series of three coordinated bomb attacks in Brussels, altogether 35 people were killed and about 340 injured;

- July 2016 - 84 people died in the crowd as a result of entering the crowd of people by a truck.

The presented events illustrate the scale of terrorist threats, and their occurrence contributed to the development of public opinion on terrorist threats. It is surprising that in August 2016, despite the series of attacks, in the opinion of the respondents the threat of terrorism was less serious than in April 2016. Paradoxically, the second half of 2016 brought a 10 percent difference from the first half. Nevertheless, the persistent $49 \%$ result of respondents declaring that there is a real threat of terrorism in Poland, on the one hand, proves a good taxation trend from 59 to 49 percent, and on the other shows a strong conviction that the terrorist attack in the country is likely.

Moreover, as the authors of the report point out, thr organized events in the country, ie the NATO summit and the World Youth Day, have significantly influenced the public perception of the competences of state institutions, and above all of the Polish authorities. The decision makers' preparation for the prevention of terrorist attacks previously assessed negatively, significantly increased from 20 percentage points to 44 percentage points (Figure 3 ).

Nowadays, Poland faces a difficult task of building the confidence of its citizens, at the same time taking into account the interests of the state in the international arena. The geopolitical location of Poland makes it necessary to conduct intensified political activities oscillating around the migration and transit security, ensuring a sense of security for the citizens and minimizing terrorist threats. 


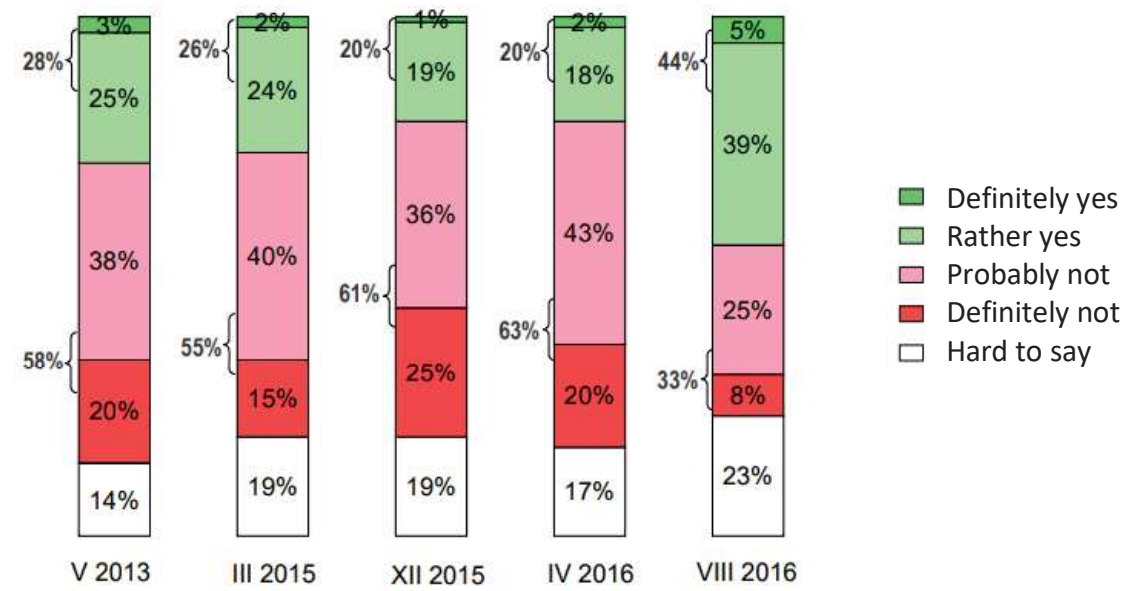

Fig. 3. Do you think that the Polish authorities, state institutions are well prepared to prevent terrorist attacks in Poland?

Source: Zagrożenie terroryzmem. Komunikat z badań, nr 127/2016, Centrum Badania Opinii Społecznej, Warsaw, September 2016, p. 4, [online], [in:] https://www.cbos.pl/SPISKOM.POL/2016/K_127_16.PDF [access 14.01.2019]

The research shows that the actions taken by state parties and the authorities create an increasingly acceptable attitude among citizens. The result of a wellconducted policy is the reduction of the real threat of terrorism in Poland in 2016 by 10 percentage points. However, in order to confirm the effectiveness of the conducted activities, it is necessary to carry out further tests confirming the described tendency.

While preparing a general sense of security profile regarding the perception of terrorist threats, a divergent result is visible. Concentrating the respondents' attention on a specific threat, the fear of the feasibility of its occurrence increases. The terrorist actions characterized by a kind of unpredictability, uncertainty, dynamism, as well as brutality and a defined purposefulness, directly influence the interpretation of this phenomenon by society.

\section{Perception of terrorist threats in institutions of education}

For the purpose of analyzing the perception and preparation of educational institutions for threats, in August 2017 some tests were carried out ${ }^{4}$. The aim of them was to familiarize the problem with the functioning of the school evacuation plans, as well as to prepare the students for taking action in the event of threats. The research was conducted by means of a survey method in the form of a questionnaire survey in postal distribution. The spreadsheets were sent to the headteachers

The research was done in cooperation with the National Security Studies Scientific Circle of the Institute of Organization and Management in the Military University of Technology. 
of 45 schools, out of which 22 answered them. The schools were selected randomly based on the secondary school ranking of the portal perspektywy.p1 ${ }^{5}$.

In the questionnaire out of the answers provided, two statements were used for the purposes of this paper, in which the respondents were asked questions about the possibility of a hostage situation and an act of terror, the results are presented in Figure 4.

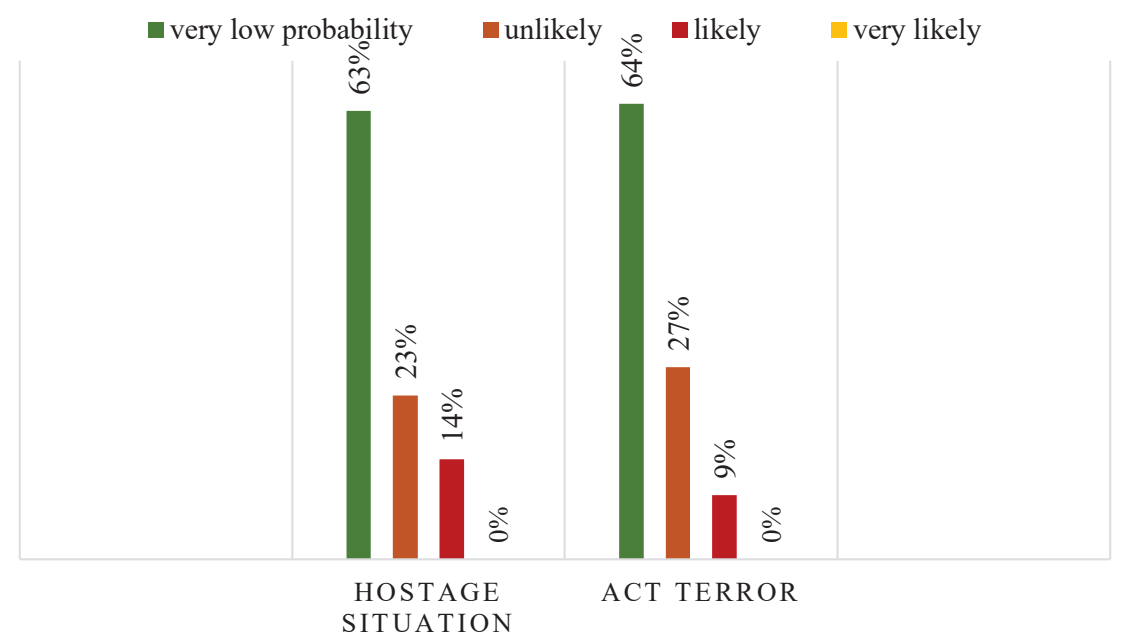

Fig. 4. Possibility of hazard in schools according to school headteachers

Source: Own research

Noting the perceived insecurity in relation to the hostage situation and the act of terror, the vast majority of respondents (63-64\%) consider these threats very unlikely and by analogy $23-27 \%$ unlikely. However, you can see the reasons for the growing sense of threat in this spectrum. In the responses provided, it was found that the situation and a terrorist act are currently unlikely, but such events cannot excepted. The emergence of the discussed threats depends on the situation in the country, as well as our neighbours. Another fair point was the formulation of the belief that in the case of terrorist threats, it does not matter how much likely the event is. The recent history shows that this type of situation most often happens in unlikely places. Selectively presented interpretations show that the two threats mentioned above begin to affect the awareness of individual persons. The dynamically changing environment forces you to analyze threats and control the sense of threat in given environments on a regular basis.

On the basis of the conducted research, it can be concluded that the perception of the occurrence of a terrorist threat in the opinion of the respondents is at a low level. However, the visible result of several percent and the respondents' statements

[online] [in:] ttp://perspektywy.pl/portal/index.php?option=com_content\&view=article\&id=3244: ranking-liceow-2017-woj-mazowieckie\&catid=221\&Itemid=424 
about the possibility of a terrorist event indicate that the problem exists and may be stronger.

The Ministry of National Education in 2017 noticed the need to introduce trainings aimed at preparing members of permanent and non-permanent institutions of education. The instructions developed by the ministry are intended to make the recipients aware of the seriousness of the problem and to work out actions to minimize the consequences of threats. In addition, as part of the Safe School project in August 2017, the Hazards document and recommended preventive actions in the field of physical and digital safety of students were developed ${ }^{6}$. The document contains some information about the emergence of new threats in educational institutions, ie the threat of cyberspace and terrorist threats. Presenting the legal conditions in the field of safety in schools, introduces the instructions and recommendations for the physical safety of schools.

The document describes the problems and proposals for action in emergency situations, the attention is drawn by a number of deficiencies that occur most often in the institutions of education. The deficiencies may be a stirring of the development of a crisis situation or at the worst a part of the planned terrorist preparations. In a synthetic way, the following elements identified with the creation of security in schools can be distinguished: the preparation of ${ }^{7}$ :

- the precincts of the school;

- the entrances of the buildings and their precincts;

- the entry / exit procedures;

- the Alarm Systems;

- the escape routes;

- the duties of the school head teachers;

- the duties of the teachers and other school staff.

The areas listed in points represent a wide spectrum of the necessary modernizations. Each school is characterized by an individual specificity of location, terrain, level of urbanization, number of people staying in the institution, etc. Thus, the preparation of an educational institution for the occurrence of threats, including terrorist threats requires a lot of time. The creation of effective action plans, the training of personnel, and above all, the preparation of non-permanent members for the possibility of a crisis situation creates a challenge for the headteachers, because it is on their shoulders that they bear the responsibility to ensure safety in and around the facility.

In relation to the above, it should be noted that the actions taken by state institutions to ensure the physical safety of students, only set out some proposed solutions along with recommendations. The problem arises with the real application of the Ministry's proposals in individual institutions. The lack of precise unification

\footnotetext{
6 Bezpieczna Szkoła. Zagrożenia i zalecane działania profilaktyczne w zakresie bezpieczeństwa fizycznego i cyfrowego uczniów, MEN, Warszawa 2017.

Ibidem, p. 10-14
} 
of the standards and the lack of imposing an obligation to introduce specific changes result in delayed implementation and delaying the modernization for a later period.

Delaying the creation of a tailored training plan and implementation of the elements affecting the safety of schools, results in an increased level of risk. Preparing the institution of education for the possibility of occurrence of dangers including terrorist threats is an elementary undertaking that results in real protection against the crisis. History shows that the aspects discussed are not an abstraction, and earlier actions taken would help to minimize or avoid a disaster.

Bearing in mind the above-mentioned elements that influence the implementation of the safe school project and implying the Ministry's recommendations, the specificity and individuality of each educational institution should be taken into account. The preparation of an effective training plan involves time and financial effort. This publication, as mentioned earlier, must take into account the external environment, the likelihood of a threat due to the institution's outposts, the urbanization, the technology and the number of permanent and non-permanent members. Such a complex statement allows you to take the first steps in creating a training plan for your school.

The preparation for terrorist threats to educational institutions seems to be activities that should be included in the school's canon these days. The school as the leading institution transferring knowledge to students from an early age, allows in the most accessible and sustainable way to acquire skills in the conduct of students in crisis situations. The acquired knowledge will allow the recipients to take the right response not only in the educational facility, but also to develop the ability to do the right things in everyday life.

\section{Summary}

The phenomenon of terrorism is a dynamic threat, and therefore relatively difficult to analyze. The possibility of its occurrence in different forms poses a challenge in the proper preparation and disposition of forces and resources in the institutions of education. However, taking steps to develop a training plan and its subsequent implementation, reduces the risk of negative succession in the event of a terrorist threat.

As demonstrated by the analysis, the general sense of security among citizens fluctuates at a very high level. This indicator is conditioned not only by the physical sense of security, but also by ensuring economic, business and developmental prosperity. The changes in the percentage result would undoubtedly be caused by security incidents, which at the moment are located under the counters of the state institutions. The effectiveness of dealing with threats by the state is clearly appreciated by its citizens. Nevertheless, the necessity to prepare training plans is visible at the moment of analyzing a specific threat. Public awareness focused on a specific phenomenon (terrorism) illustrates the level of threat to a much different extent. It can 
be assumed that in a chosen spectrum, a sense of security is significantly displaced by a threat. This is confirmed by the results of the surveys presented in the paper.

The current, relatively stable situation in the country allows us to take up the challenge of creating a training system that will prepare members of permanent and consecutive non-permanent education institutions for threats. Terrorism as a phenomenon adopting non-standard forms, enforces the creation of a training program that takes into account the stages of education, the skills and age of participants, and thus the psychological capabilities of the listeners. It should be noted that the overall activities aimed at increasing the physical security of schools should consist of successively introduced stages. The first action is the creation of a tailored physical security plan for a given facility. Successively conducted by experts a series of theoretical and practical training for permanent members, taking into account different scenarios of terrorist threats. After the implementation of the above stages, it is possible to transfer the acquired knowledge to non-permanent members of the educational institution. Students, as well as teachers, should familiarize themselves with the theoretical knowledge and participate in practical classes. The best solution is to transfer knowledge along with the skills acquired by the teachers in the assistance of the experts preparing the training.

The concept of raising safety, as well as the awareness and skills of the recipients in the event of terrorist threats, presented in a synthetic way, will enable in the event of danger to take action not only in the educational institution, but also in everyday life. The ability to deal with threats is an art that has been developed for years. The introduction of training in the form of a compulsory school curriculum will also allow to prepare the society gradually for crisis situations, effective analysis of threats together with taking actions adequate to the situation.

BIBLIOGRAPHY

[1] Bezpieczna szkoła. Zagrożenia i zalecane działania profilaktyczne w zakresie bezpieczeństwa fizycznego i cyfrowego uczniów, MEN, Warszawa 2017.

[2] Bolechów B., Terroryzm. Aktorzy, statyści, widownie, PWN, Warszawa 2010.

[3] Liedel K., Piasecka P., Jak przetrwać $w$ dobie zagrożeń terrorystycznych. Elementy edukacji antyterrorystycznej, Trio, Warszawa 2008.

[4] PAprzycki L., Rau Z., Praktyczne elementy zwalczania przestępczości zorganizowanej i terroryzmu. Nowoczesne technologie i praca operacyjna, Wolters Kluwer Polska, Warszawa 2009.

[5] Sienkiewicz-MaŁYjurek K., Skuteczne zarządzanie kryzysowe, Difin, Warszawa 2015.

[6] Skrabacz A., Sulowski S. (red.), Bezpieczeństwo społeczne, pojęcia, uwarunkowania, wyzwania, Elipsa, Warszawa 2012.

[7] Zieliński K., Ochrona ludności. Zarządzenie kryzysowe, Difin, Warszawa 2017. 


\section{Netografia}

[1] https://www.cbos.pl/

[2] https://www.portalbhp.pl/zarzadzania-bezpieczenstwem-i-higiena-pracy/atakterrorystyczny-w-szkole-7972.html

[3] http://www.lostrzelin.pl/Proc_post_w_przyp_zagro_terroryzmem.pdf

\section{LAPIDARNA PERCEPCJA ZAGROŻEŃ TERRORYSTYCZNYCH W INSTYTUCJACH OŚWIATY}

Streszczenie. Autor podejmuje próbę przybliżenia postrzegania zagrożeń terrorystycznych w instytucjach oświaty. W celu obiektywności prowadzonej analizy zestawia badania przeprowadzone przez Centrum Badania Opinii Społecznej prezentujące poczucie bezpieczeństwa w kraju oraz postrzeganie zagrożeń terrorystycznych z badaniami własnymi wykonanymi w placówkach oświaty. Analizując wyniki oraz zwracając uwagę na wytyczne Ministerstwa Edukacji Narodowej, określa budowę wstępnego planu działalności szkoleniowej w ramach projektu „Bezpieczna Szkoła”.

Słowa kluczowe: bezpieczeństwo instytucji oświaty, zagrożenia terrorystyczne, bezpieczeństwo uczniów, przygotowanie szkół na zagrożenia terrorystyczne. 